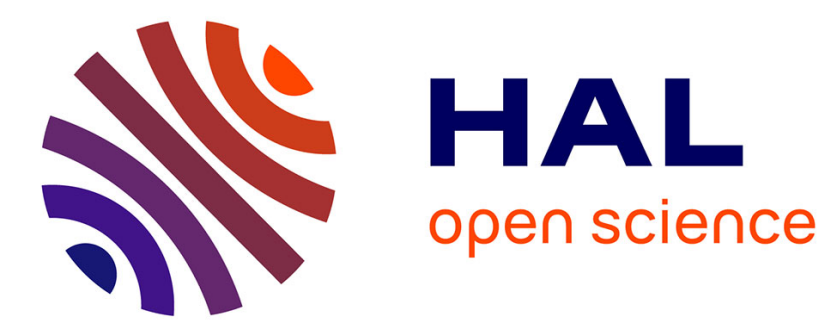

\title{
Experimental study of swelling in unsaturated compacted clays
}

Nadia Saiyouri, Dominique Tessier, Pierre-Yves Hicher

\section{To cite this version:}

Nadia Saiyouri, Dominique Tessier, Pierre-Yves Hicher. Experimental study of swelling in unsaturated compacted clays. Clay Minerals, 2004, 39 (4), pp.469 - 479. 10.1180/0009855043940148 . hal01006853

\section{HAL Id: hal-01006853 \\ https://hal.science/hal-01006853}

Submitted on 8 Apr 2017

HAL is a multi-disciplinary open access archive for the deposit and dissemination of scientific research documents, whether they are published or not. The documents may come from teaching and research institutions in France or abroad, or from public or private research centers.
L'archive ouverte pluridisciplinaire HAL, est destinée au dépôt et à la diffusion de documents scientifiques de niveau recherche, publiés ou non, émanant des établissements d'enseignement et de recherche français ou étrangers, des laboratoires publics ou privés. 


\title{
Experimental study of swelling in unsaturated compacted clays
}

\author{
N. SAIYOURI ${ }^{1}$, D. T E S I E R ${ }^{2}$ AND P. Y. HICHER ${ }^{1}$ \\ ${ }^{1}$ Institut de Recherche en Génie Civil et Mécanique, CNRS UMR 6183, Ecole Centrale de Nantes-Université de Nantes, \\ 44321 Nantes Cedex 3, and ${ }^{2}$ INRA, Station de Science du Sol, Route de Saint Cyr, 78026 Versailles Cedex, France
}

\begin{abstract}
This paper describes the swelling properties of two highly compacted clays, natural, untreated Wyoming montmorillonite (MX80) and Fourges smectite (FoCa7), saturated with $\mathrm{Na}$ and $\mathrm{Ca}$, respectively.

The initially compacted samples were hydrated by subjecting them to different suction pressures in a range between $100 \mathrm{MPa}$ and $1 \mathrm{kPa}$. For each equilibrium state, the volume change (swelling) and water content (hydration) were measured. The samples were then studied by X-ray diffraction using a transmission device to determine interlayer distance and particle size, in order to clarify both the swelling and hydration mechanisms. The distances between clay layers ranged between 10 and 21.6 $\mathrm{A}$, i.e. corresponding to between 0 and 4 water layers. Upon hydration, the particle size decreased from 350 and 100 clay layers per particle to 10 layers per particle when the suction pressure decreased from $100 \mathrm{MPa}$ to $1 \mathrm{kPa}$ for MX80 and FoCa7, respectively. The first swelling stage is described as being an insertion of water molecules between the layers. Then a division of the initial particles into particles of smaller size with increasingly large inter-particle distances was observed. Observations by transmission electronic microscopy confirmed these results.
\end{abstract}

KEYwORDS: clays, swelling, suction pressure, microstructure, X-ray diffraction, hydration, Ca-smectite, NaWyoming montmorillonite

Clays have long been used as impermeable media for retaining water. In landfills, they contribute to solutions used for stopping the transport of pollutants (Marcoen \& Tessier, 1991). In Europe, smectites are generally used for these purposes and are mostly commercially available bentonites from the large European (Greece, Sardinia) or American (Wyoming in particular) deposits. In France, the Fourges clay, among others, was selected by "Commissariat à l'Energie Atomique" as a filling material for interposing between the waste containers and the host rock in the disposal of radioactive wastes in deep geological formations (Coulon, 1987; Saiyouri, 1996). This material has advantageous swelling properties (Tessier et al., 1992) and can be processed industrially by highpressure compacting.

The organization of a water-clay system depends on the size of elementary particles, their swelling state and their mutual arrangement which controls the pore structure and consequently the permeability of the system.

From a mechanical point of view, clay swelling involves a modification of the internal strain state. Numerous authors (Méring, 1946; Aylmore \& Quirk, 1962; Yong et al., 1963; Kassif \& Ben Shalom, 1971; Tessier, 1978) have studied swelling mechanisms. Different models have also been developed to predict the swelling of clay materials (Warkentin et al., 1957; Kjellander et al., 1988a,b; Delville \& Laszlo, 1990; Yong, 1999). For smectites, they showed that swelling occurs in two 
stages: the first is the insertion of water between the elementary clay layers; the second is the filling of larger spaces. The relative importance of the two mechanisms is different depending on whether the clay is calcic or sodic. Insertion of water between clay layers can occur on a large scale for $\mathrm{Na}$ montmorillonite, but is more limited for $\mathrm{Ca}$ smectite and does not occur for kaolinite (Aylmore \& Quirk, 1962; Ben Rhaeïm et al., 1987). Furthermore, it is often thought that clay swelling is a mechanism which intervenes only between clay-layer units. This is largely true for sodic smectites but not for calcic smectites. Crystal units as well as aggregates of these crystals and their mutual arrangements can also play an important part in this mechanism. In the same way, the evolution of the structure of clays also depends on the energy history. While clay structure evolution is well known for drying paths, such is not the case for wetting paths, especially from initially highly compacted states.

The aim of this paper is to understand the swelling mechanism for highly compacted clays. Two clays were wetted in order to establish comparisons and explain differences in their behaviour (Saiyouri, 1996). X-ray diffraction (XRD) by transmission was used in order to describe the various levels of clay organization. This was completed by electron microscopy observations in order to show the role of the parameters that intervene in the swelling mechanism for improving predicting models.

\section{MATERIALS AND METHODS}

\section{Clays studied}

A smectite clay, referred to here as FoCa7, was selected. It comes from Fourges in the Paris basin and is extracted from a deposit of Sparnacian age (Tessier et al., 1998). It is $85 \%$ smectite-kaolin with the latter being half kaolinite and half beidellite, and $2 \%$ quartz, with goethite in trace amounts (Bruno, 1993).

A naturally sodic Wyoming montmorillonite (MX80) was also used for the experiments. This clay contains a small amount of quartz and mica (Tessier, 1984).

These samples were prepared from a powder $(<2 \mu \mathrm{m})$ which was subjected to isotropic mechanical compaction applied by an isostatic press up to $60 \mathrm{MPa}$. Their initial water content was $\sim 10 \%$, which is the value corresponding to equilibrium with atmospheric relative humidity at room temperature $(\sim 60 \% \mathrm{RH})$. From this initial state, the samples were hydrated to high water-content values by decreasing the imposed suction.

In order to obtain the mineralogical composition of the clay samples, we carried out XRD analysis by using a reflection device applied to oriented specimens of powder FoCa7 and MX80. Each peak was identified by its position and shape. The XRD of oriented specimens was performed at room temperature, after heating and after ethylene glycol treatment. To quantify accurately the amount of kaolinite in the FoCa7 clay, thermogravimetric analyses were used.

Physical-chemical characteristics of the clays were measured (with $85 \%$ clay material). The cation exchange capacity (CEC) and exchangeable cations were determined using cobaltihexamine as the saturating cation (Ciesielsky et al., 1997). The monoethyl ether ethylene glycol method was used to determine total surface area (Heilman et al., 1965). Nitrogen sorption isotherms were also carried out after outgassing at $22^{\circ} \mathrm{C}$ under a residual pressure with the normal procedure. The external surface area was deduced from the BET formalism (Brunauer, Emmett \& Teller equation). The results showed that the total surface area is compatible with smectitic clays but is greater for MX80 than for FoCa7 (Table 1).

TABLE 1. Total and external surface area, exchangeable cations and CEC for untreated FoCa7 and untreated MX80 clays.

\begin{tabular}{lccccr}
\hline Clay & $\begin{array}{c}\mathrm{BET} \\
\left(\mathrm{m}^{2} \mathrm{~g}^{-1}\right)\end{array}$ & $\begin{array}{c}\mathrm{EGME} \\
\left(\mathrm{m}^{2} \mathrm{~g}^{-1}\right)\end{array}$ & $\begin{array}{c}\mathrm{CEC}\left(\mathrm{cmol}^{+} \mathrm{kg}^{-1}\right) \\
\text { with CH }\end{array}$ & $\begin{array}{c}\mathrm{Na}\left(\mathrm{cmol}^{+} \mathrm{kg}^{-1}\right) \\
\text { with CH }\end{array}$ & $\begin{array}{c}\mathrm{Ca}_{\left(\mathrm{cmol}^{+} \mathrm{kg}^{-1}\right)} \\
\text { with CH }\end{array}$ \\
\hline FoCa7 & 41 & 453.66 & 69.1 & 2.64 & 62.90 \\
MX80 & 18.8 & 522.03 & 82.3 & 79.80 & 5.28 \\
\hline
\end{tabular}

CH: cobaltihexamine 
Scanning transmission electron microscopy (STEM) analyses with energy dispersive spectroscopy (EDS) technique were used to calculate the structural formula of the FoCa7 smectite (Gin et al., 2001). About 100 analyses on nine samples of clay were carried out to determine it on the basis of 12 oxygens. This allowed the parameters needed for calculating X-ray diffused intensities to be determined (Pons, 1980). The formula for FoCa7 and Wyoming smectites are respectively:

$$
\begin{aligned}
& \left\{\mathrm{Si}_{3.59} \mathrm{Al}_{0.41}\right\} \mathrm{O}_{10}\left\{\mathrm{Al}_{1.65} \mathrm{Fe}_{0.30} \mathrm{Mg}_{0.16}\right\} \mathrm{OH}_{2} \mathrm{Ca}_{0.12} \\
& \left\{\mathrm{Si}_{3.96} \mathrm{Al}_{0.04}\right\} \mathrm{O}_{10}\left\{\mathrm{Al}_{1.53} \mathrm{Fe}_{0.18}^{3+} \mathrm{Mg}_{0.26} \mathrm{Ti}_{0.01}\right\} \\
& \mathrm{OH}_{2} \mathrm{Na}_{0.34} \mathrm{~K}_{0.01}
\end{aligned}
$$

For FoCa7 clay, the layer charge is a 0.24 negative charge per half unit cell, while for Wyoming clay the layer charge is 0.34 .

\section{Water retention and volume change measurements}

The initial size of the compacted sample was $\sim 10 \mathrm{~cm}^{3}$. It was separated into small fragments for hydration experiments. Three replicate samples of these fragments $\left(\sim 1 \mathrm{~cm}^{3}\right)$ were hydrated in order to obtain water retention and swelling curves. Three methods were used to impose the suction pressures (Tessier \& Berrier, 1979; Ben Rhaeïm et al., 1987). Increasing air pressure from $1 \mathrm{kPa}$ to $100 \mathrm{kPa}$ and $1 \mathrm{MPa}$, allowed the water to re-hydrate the samples through the filter up to equilibrium (constant weight).

For $1 \mathrm{kPa}, 3.2 \mathrm{kPa}, 10 \mathrm{kPa}, 32 \mathrm{kPa}$ and $100 \mathrm{kPa}$, the measurements were made by applying air

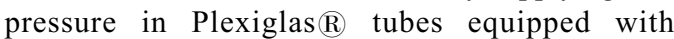
$0.22 \mu \mathrm{m}$ pore filters. For $1 \mathrm{MPa}$ suction pressure value, a high-pressure membrane cell equipped with a membrane dialysis (1.8 $\mathrm{nm}$ pore size) was used.
Higher suction pressure values (between $2 \mathrm{MPa}$ and $107 \mathrm{MPa}$ ) were imposed by controlling relative humidity. This was achieved by using desiccators containing saturated salt solutions (Table 2) according to Tessier (1975).

After equilibrium, the water content was determined by heating the sample at $105^{\circ} \mathrm{C}$, for $48 \mathrm{~h}$. For measuring apparent volume, a method developed by Tessier \& Berrier (1979) was used which consists of measuring Archimedes pressure exerted on the specimen immersed in kerosene (AFNOR standard, 1994). The volume and watercontent changes will be given in water content: water weight/solid weight in $\mathrm{g} \mathrm{g}^{-1}$. The void ratio $e$ is defined as the ratio of void volume $\left(V_{\mathrm{v}}\right)$ on solid volume $\left(V_{\mathrm{s}}\right)$.

\section{XRD measurements}

Interlayer distances during swelling-shrinking cycles and the particle size of the samples were measured on XRD patterns. In order to study internal structure at the different steps of wetting, slices of the samples, $\sim 0.5 \mathrm{~mm}$ thick, were cut. The apparatus is a Siemens $\AA$ D5000 $\theta / 2 \theta$ X-ray diffractometer, mounted in transmission mode and fitted with a copper tube $\left(K \alpha_{1} \mathrm{~nm}\right)$, a primary monochromator, Soller slits, adjustable divergence slits, a $\phi$ circle and a linear localization detector (Elphyse $\mathrm{B}$ ).

A brass cell was used during data acquisition. It was mounted with two mica windows and was closed by a screw cap with a doughnut ring to avoid water evaporation. The samples were transferred directly from the filtration cell into the air-tight cell. A slice of the clay was set between the two mica windows and the cell was closed immediately. The setting in transmission mode was described by

TABLE 2. Salt solutions and corresponding relative humidity used for FoCa7 and MX80 clays (Tessier, 1975).

\begin{tabular}{lcl}
\hline $\begin{array}{c}\text { Suction pressure } \\
(\mathrm{MPa})\end{array}$ & $\begin{array}{c}\text { Relative humidity } \\
(\%)\end{array}$ & Saturated salt solution \\
\hline 2 & 98 & $\mathrm{CuSO}_{4} .5 \mathrm{H}_{2} \mathrm{O}$ \\
6 & 95 & $\mathrm{Na}_{2} \mathrm{SO}_{3} .7 \mathrm{H}_{2} \mathrm{O}$ \\
15 & 90 & $\mathrm{ZnSO}_{4} .7 \mathrm{H}_{2} \mathrm{O}$ \\
26 & 81 & $\left(\mathrm{NH}_{4}\right)_{2} \mathrm{SO}_{4}$ \\
33 & 79.5 & $\mathrm{NH}_{4} \mathrm{Cl}$ \\
56 & 66 & $\mathrm{NaNO}_{2}$ \\
107 & 47 & $\mathrm{KCNS}$ \\
\hline
\end{tabular}


Iñigo et al. (2000). The $\theta$ ring did not move. The sample turned in a plane normal to the X-ray beam. The detector was positioned to record the transmitted X-ray in the chosen angular range, in our case $1-15^{\circ} 2 \theta, \mathrm{Cu}-K \alpha_{1}$.

Before discussing the role of the different parameters, we will specify the vocabulary used in the following concerning clay particles or aggregates.

Quasi-crystals are parallel stacks of face to face clay layers (Aylmore \& Quirk, 1962). They can be separated by layers of water molecules. The quasicrystals gather in order to form particles. The spaces between them constitute the inter-quasi-crystal porosity. Particles can be identified and separated by larger size pores, which are collectively referred to as inter-particle porosity. The X-ray method by transmission is particularly suitable for studying water location and the hydration mechanism of clay samples (Pons et al., 1981, 1982). The X-ray profiles cannot be interpreted directly, as XRD depends on different parameters. We applied an indirect method, based on Pons' structural modelling (Pons et al., 1981). The method provided information on the evolution of distance between the layers $\left(d_{i}\right)$, on the particle size distribution and on the number of layers per particle $(M)$. It also gave the probabilities $\left(p_{i}\right)$ for the different quoted parameters to have those values.

The parameters were obtained by a fitting of the theoretical curve compared to the experimental one (Pons et al., 1981). The theoretical curve was determined from the diffused intensity by the system, which is crossed by the X-ray beam.

After Pons (1980), the diffused intensity by a smectite system can be written as:

$$
I(\mathrm{~s})=\frac{1}{2 \pi \Omega} \frac{|F(\mathrm{~s})|^{2}}{\mathrm{~s}^{2}} \sum \alpha(M) G\left(\mathrm{~s}, M, p_{i}, d_{i}\right)
$$

where $\mathbf{s}$ is the diffusion vector. $F(\mathrm{~s})$ is the structure factor in the direction perpendicular to the layer plane. $\alpha(M)$ is the weight distribution in particle thickness. $G(M)$ is the modulation function determined by Méring (1946). $G(M)$ can be written as:

$G\left(\mathbf{s}, M, P_{i}, d_{i}\right)=1+2 \operatorname{Re}\left[\sum_{n=1}^{M-1} \frac{M-n}{M} Q^{M}\left(\mathbf{s}, p_{i}, d_{i}\right)\right]$

where $Q\left(\mathbf{s}, p_{i}, d_{i}\right)$ is a function which expresses the nature of interference between two adjacent layers (Ben Rhaïem et al., 1987).
In our case, i.e. where the transition between two layers is made of $\mathrm{r}$ translations $d_{1}, d_{2}, \ldots d_{r}$ with respective probabilities $p_{1}, p_{2}, \ldots p_{r}$, the $Q\left(s, p_{i}, d_{i}\right)$ function takes the following form (Ben Rhaiem et al., 1987):

$$
Q(\mathbf{s})=\sum_{i=1}^{r} P_{i} \exp \left(2 \pi \mathbf{s} d_{i}\right)
$$

with:

$$
\sum_{i=1}^{r} P_{i}=1
$$

In the particular case of montmorillonite, the structure factor is known (Pons et al., 1981); we can simultaneously find the number of layers per particle $M$, and the distances $d_{i}$ with their corresponding probabilities $p_{i}$.

Literature data show that the model is very sensitive to clay texture, both in the range of low angle and in the classical Bragg diffraction range. Our experience shows that only one combination of the model fits correctly to the experimental diagram. Furthermore, it has been shown that there is a good agreement between TEM observations of wet samples when their microstructure is preserved in appropriate conditions and XRD measurements (Elsass et al., 1998).

An example of adjustment between the experimental curve and Pons' model is given in Fig. 1 for MX80 at $10 \mathrm{kPa}$. In this particular case, it was possible to determine, at the same time, the

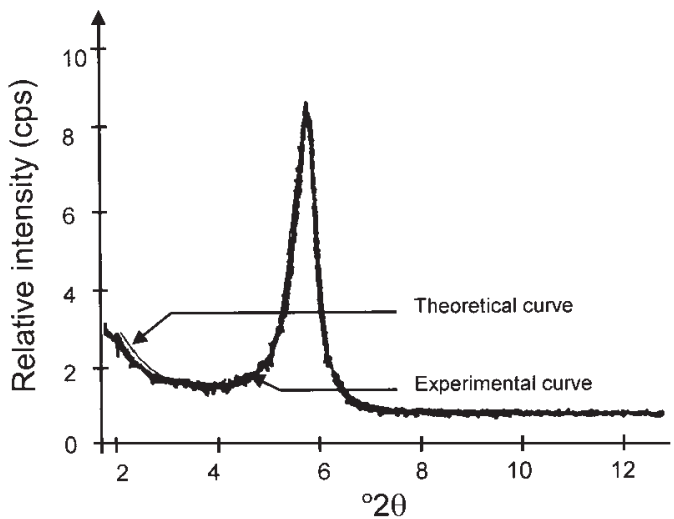

Fig. 1. Example of fitting between theoretical and experimental XRD curves for MX80 clay at $10 \mathrm{kPa}$ suction pressure. The apparent distance is close to $19 \AA$. 
distribution of the interlayer distance with their respective probability and the average number of layers stacked on top of each other. From these results, it was possible to calculate water distribution according to the surface area and number of layers of the particles.

\section{Transmission electron microscopy}

The hydrated samples of FoCa7 and MX80 prepared at a given suction pressure were observed by TEM. Wet fragments of a few millimetres were embedded in an epoxy resin (Tessier, 1984; Kim et al., 1995; Elsass et al., 1998). After embedding, the samples were heated in an oven at $60^{\circ} \mathrm{C}$, for $48 \mathrm{~h}$, in order to allow a complete polymerization of the resin. The thin sections ( $\sim 50 \mathrm{~nm}$ thick) were obtained by using a diamond knife.

\section{RESULTS}

\section{Water content and volume change}

The samples were hydrated from a very strongly compacted initial state. As these clays were of
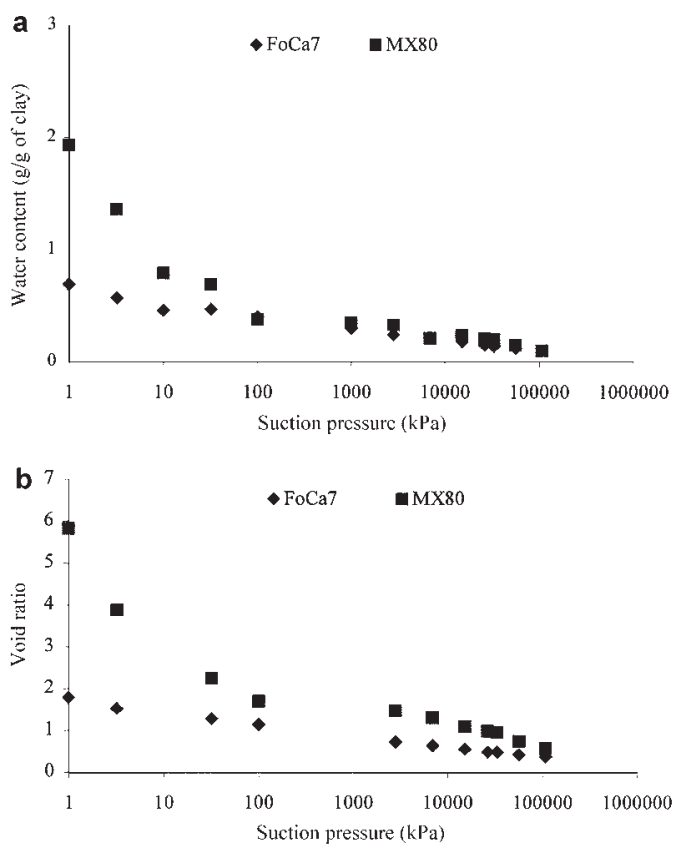

FIG. 2. Water content "w $=$ water weight/dry solid weight" (a) and void ratio (b) vs. suction pressure for FoCa7 and MX80 clays. different nature, their behaviour differed from the view point of water retention as well as volume change. Wetting curves showed that the MX80 clay had a greater water content than FoCa7 clay, especially in the range of suction pressures $<100 \mathrm{kPa}$ (Fig. 2a). We also observed that the water content values constantly increased with decreasing suctions. For MX80, the water content reached at $1 \mathrm{kPa}$ is $\sim 200 \%$, while for FoCa7, it is only 68\% (Saiyouri et al., 2000).

The void ratio values had the same tendency, i.e. $e=5.8$ for MX80 and $\sim 2$ for FoCa7 at $1 \mathrm{kPa}$, while at the beginning of the experiment, at $100 \mathrm{MPa}$ of suction pressure, the void ratio is equal to 0.6 and 0.4 for MX80 and FoCa7, respectively (Fig. 2b). It was concluded that MX80 was less saturated with water than $\mathrm{FoCa} 7$, since the degree of saturation with water was $94 \%$ (6\% air) and $100 \%(0 \%$ air in the porosity space) for MX80 and FoCa7, respectively, at $1 \mathrm{kPa}$.

\section{Layer distance and particle-size distribution}

X-ray diffraction experiments were carried out at different suction pressures and for three sample orientations, as shown in Fig. 3, for MX80 clay at $10 \mathrm{kPa}$. The intensity of the diagrams was very similar whatever the sample orientation, both for FoCa7 and MX80 clay. This is probably due to the initial state of the samples which were prepared from a powder and subjected to an isotropic

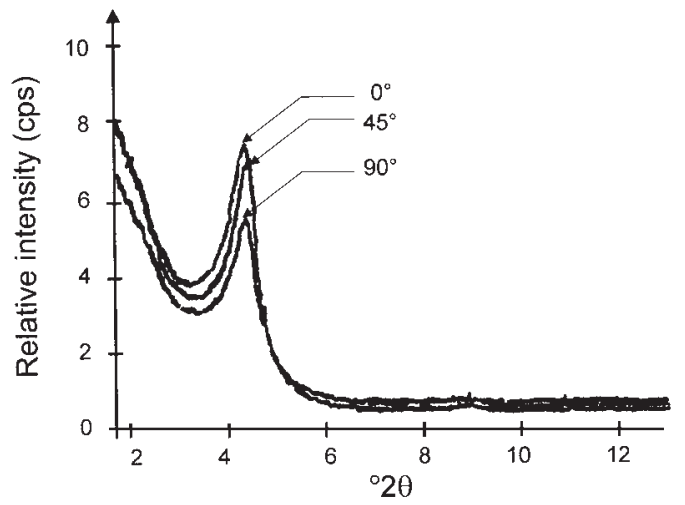

FIG. 3. XRD patterns for MX80 clay at $10 \mathrm{kPa}$, at 0,45 and $90^{\circ}$ rotation angles. The peak intensity is similar for different orientations showing an isotropic orientation due to isotropic compaction. 
compaction. Thus, after rewetting, the particle arrangement remained mainly isotropic. This is different from experiments by Iñigo et al. (2000) who showed a strong orientation when the clay was prepared as a paste and submitted to drying and wetting cycles. The diagram intensity ratio was $\sim 10$ for Iñigo et al. (2000) when it was only $1-1.2$ for our clays. Thus we concluded that, even after wetting, the compacted clays exhibited an isotropic orientation, and it is very important to know the initial state of the sample to discuss particle orientation.

From XRD diagrams and by using Pons' model, one can specify the mean interlayer distance during wetting (Fig. 4). The probability for each interlayer distance, from 0 to 4 water layers, is given in Table 3. Note the presence of non-hydrated layers

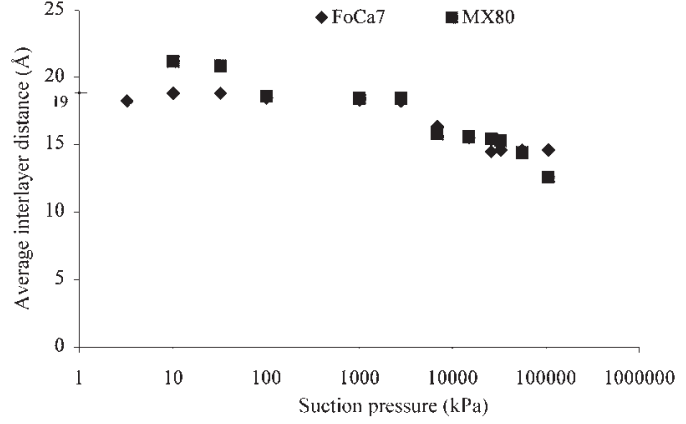

FIG. 4. Average interlayer distances vs. suction pressure for FoCa7 and MX80. Note that the apparent distance is close to $19 \AA$.

TABLE 3. Probability distribution as a function of suction pressures for $\mathrm{FoCa} 7$ and MX80, respectively. Note that the layer distances range from 10 to $21.6 \AA$ according to the mean layer distance close to $19 \AA$.

\begin{tabular}{|c|c|c|c|c|c|}
\hline $\begin{array}{l}\text { FoCa7 } \\
\text { Suction pressure } \\
\quad(\mathrm{kPa})\end{array}$ & $\begin{array}{c}0 \text { layer } \\
10 \AA\end{array}$ & $\begin{array}{l}1 \text { layer } \\
12.6 \AA\end{array}$ & $\begin{array}{l}2 \text { layers } \\
15.6 \AA\end{array}$ & $\begin{array}{c}3 \text { layers } \\
18.6 \AA\end{array}$ & $\begin{array}{l}4 \text { layers } \\
21.6 \AA\end{array}$ \\
\hline 10 & 0.07 & 0.10 & 0.14 & 0.29 & 0.32 \\
\hline 32 & 0.07 & 0.10 & 0.14 & 0.29 & 0.32 \\
\hline 100 & 0.07 & 0.10 & 0.15 & 0.30 & 0.33 \\
\hline 1000 & 0.07 & 0.16 & 0.16 & 0.25 & 0.25 \\
\hline 2800 & 0.074 & 0.167 & 0.167 & 0.25 & 0.25 \\
\hline 6900 & 0.10 & 0.26 & 0.26 & 0.17 & 0.17 \\
\hline 1500 & 0.15 & 0.25 & 0.25 & 0.18 & 0.17 \\
\hline 26000 & 0.15 & 0.32 & 0.28 & 0.25 & 0 \\
\hline 33000 & 0.15 & 0.30 & 0.28 & 0.27 & 0 \\
\hline 56000 & 0.12 & 0.35 & 0.27 & 0.26 & 0 \\
\hline 107000 & 0.12 & 0.35 & 0.27 & 0.26 & 0 \\
\hline MX80 & 0 layer & 1 layer & 2 layers & 3 layers & 4 layers \\
\hline $\begin{array}{l}\text { Suction pressure } \\
\quad(\mathrm{kPa})\end{array}$ & $10 \AA$ & $12.6 \AA$ & $15.6 \AA$ & $18.6 \AA$ & $21.6 \AA$ \\
\hline 10 & 0 & 0 & 0,32 & 0.32 & 0.2 \\
\hline 32 & 0 & 0 & 0.32 & 0.32 & 0.2 \\
\hline 100 & 0 & 0 & 0.2 & 0.6 & 0.2 \\
\hline 1000 & 0 & 0 & 0.33 & 0.33 & 0.33 \\
\hline 2800 & 0 & 0 & 0.33 & 0.33 & 0.33 \\
\hline 6900 & 0 & 0.22 & 0.5 & 0.28 & 0 \\
\hline 15000 & 0 & 0.15 & 0.7 & 0.15 & 0 \\
\hline 26000 & 0 & 0.23 & 0.6 & 0.17 & 0 \\
\hline 33000 & 0 & 0.3 & 0.5 & 0.2 & 0 \\
\hline 56000 & 0.1 & 0.3 & 0.5 & 0.1 & 0 \\
\hline 107000 & 0.18 & 0.64 & 0.18 & 0 & 0 \\
\hline
\end{tabular}


(10 $\mathrm{A})$ for FoCa7. In the range of suction pressures $<\sim 1000 \mathrm{kPa}$, this distance was larger for MX80 than for FoCa7. FoCa7 and MX80 have a globally similar behaviour at the beginning of the hydration process. The interlayer distance increased from 1 to 2 water layers from the lowest to the highest water contents at $\sim 60 \mathrm{MPa}$ (distance increases from 12.6 to $15.6 \AA$ ). The transition from 15.6 to $18.6 \AA$ occurred at a suction pressure of $\sim 4 \mathrm{MPa}$ for both FoCa7 and MX80. However, the latter exhibited some differences compared to that of FoCa7 since another transition appeared at $\sim 50 \mathrm{kPa}$ and led to a layer spacing of $21.6 \AA$ (four water layers). It must be noted however that distances $>21.6 \AA$ did not really appear and that crystal swelling was thus limited to four water layers and not beyond. The model described a system with different layer distances including the presence of $10 \AA$ layer distance, i.e. dehydrated mica layers (illitic phase), up to $15 \%$ for very high suction pressures.

On the other hand, the mean number of layers $(M)$ per particle made it possible to determine particle size and to characterize the clay organization (Fig. 5). It decreased as water content increased both for MX80 and FoCa7. At the lowest water content, each particle was composed of an average of 100 layers $(M)$ in the case of FoCa7, whereas $M$ was 350 layers for MX80. When the water content increased, the mean number of layers per particle, as seen by XRD patterns, decreased to 10 layers at $1 \mathrm{kPa}$. It thus appeared that particle size varied with a ratio of 10 for $\mathrm{FoCa} 7$ and 35 for MX80 clay between the initial state $(100 \mathrm{kPa})$ and the highest hydrated state $(1 \mathrm{kPa})$.

It is clear that the calculations made on $\mathrm{FoCa} 7$ took into account an average clay composition given by the structural formula that does not really

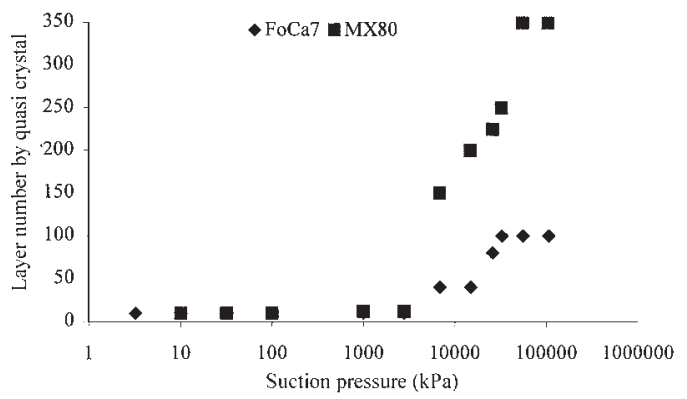

Fig. 5. Number of layers per particle vs. suction pressure for FoCa7 and MX80. During hydration the quasi-crystals are divided into smaller crystals up to $\sim 10$ layers at $10 \mathrm{kPa}$. represent the complexity of the clay particle composition. Thus, the structural factors calculated from Pon's model do not precisely describe the microstructure of FoCa7. The results confirm the complexity of the system with the coexistence of illitic layers.

\section{TEM observations}

Low-magnification TEM images were obtained at $10 \mathrm{kPa}(\times 10,000)$ (Fig. 6a,b). According to their extension in the $a b$ plane, the MX80 clay texture was considerably larger than that of the FoCa7. However both clays exhibit a texture and an organization typical of smectites.

\section{DISCUSSION AND IN TERPRETATION}

\section{Origin and significance of the isotropic structure}

The Wyoming (MX80) and Fourges (FoCa7) montmorillonites were studied after strong isotropic compaction, but without special preparation, i.e. in their original state. The physicochemical study showed that FoCa7 clay was mainly a Ca-saturated clay while the MX80 clay was Na-saturated. In agreement with the CEC measurements, the specific surface area, obtained using the EGME method, was slightly greater for MX80 $\left(522 \mathrm{~m}^{2} / \mathrm{g}\right)$ than for FoCa7 $\left(453 \mathrm{~m}^{2} / \mathrm{g}\right)$. This is probably due to the presence of kaolinite and also an illitic phase (Table 3) in FoCa7, in addition to the nature of exchangeable cations. Even if these parameters are important in the behaviour of materials, they could not explain the essence of the behaviour of these clays, especially at high water contents. Because the nature of the exchangeable cations was different, very different macroscopic properties and swelling mechanisms could be expected for $\mathrm{Ca}$ - and $\mathrm{Na}$-smectite. The initial compaction of the samples needs to be considered closely in this section because it can probably explain the behaviour differences between these clays and those usually described in literature. Different measurements and XRD made it possible to follow simultaneously the whole wetting curve (hydration-volume change) and microscopic behaviour (layer distance distribution, particle size, orientation). Thus X-ray diffraction by transmission allowed us to identify two main levels of clay 

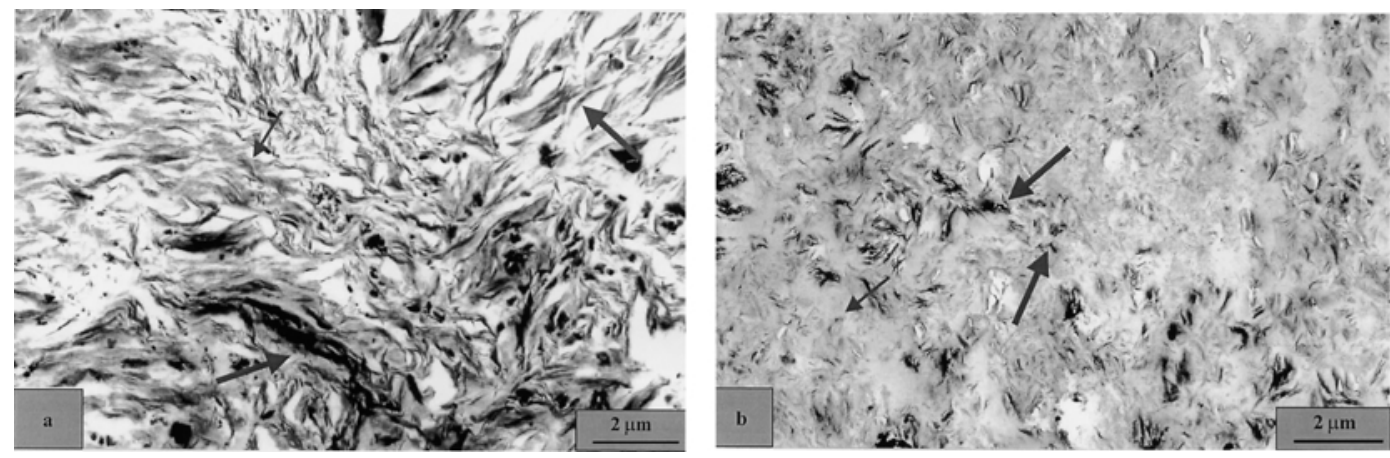

FIG. 6. Low-resolution TEM images of the clays equilibrated at a suction pressure of $10 \mathrm{kPa}$ : (a) FoCa7 showing large $2 \mu \mathrm{m}$ sized quasi-crystals (see arrow) mainly organized face to face. (b) MX80 showing an isotropic network of fine and larger quasi-crystals.

organization but also to obtain information about overall orientation. Because the clay appeared to be randomly oriented, we concluded that, in our case, the clay particles were organized in an isotropic way. This can be explained by the fact that the initial compaction was performed isotropically on the clay powder. However, even if the system observed by X-ray was isotropic, it does not mean that a structural order is not present at different scales. Indeed, an overall disorder can arise at the particle level, but it does not prevent a local order at the layer scale.

\section{Microstructure evolution and water location}

Based on the evolution of the parameters of Pons' (1980) model, the layer-distance distribution in the clay can be followed. This model is very sensitive to the probability parameters noted above. If we change one of the probability values to have an inter-layer distance, the combination obtained ( $M, d$ and $p$ which is the disorder parameter) is very different from the former and the theoretical curve given by the model does not simulate well the experimental one. The set of parameters for every experimental curve is difficult to obtain because of the lack of uniqueness (Pons, 1980; Pons et al., 1982). Clay swelling starts at the adsorption of water molecules between individual clay layers. The interlayer distance then does not exceed $21.6 \AA$, which is rather unusual for Na-montmorillonite. For instance, Tessier (1991) found layer distances close to $100 \AA$ after rewetting $\mathrm{Na}$ Wyoming montmorillonite. In gels, the distance reaches $\sim 100 \AA$ with dilute solutions (Norrish,
1954). Our interpretation is that the initial strongly-compacted state of the clay $(60 \mathrm{MPa})$ could prevent such a swelling beyond four water layers at most. Two complementary elements can explain this behaviour: an order in the stacking of the layers acquired under the effect of mechanical compaction and a mechanical effect with an increase of friction forces at the time of hydration (Suquet, 1978) similar to that described during desiccation.

Discovering strong hydration, thus, does not involve swelling on the scale of the layers but appears related to obtaining an increasingly large external surface of the quasi-crystals caused by a progressive division of these particles. However these particles still develop a small surface compared to that of the total layer surface area.

From these results it becomes possible to determine water location. The Pons model allows us to estimate the amount of water between clay layers by giving the probabilities $\left(p_{i}\right)$ of the number of water layers located in the interlayer spaces. The specific surface area can be multiplied by the number of water layers deduced from X-ray measurements. The results are the water volumes $V 1, V 2, V 3$ and $V 4$ which correspond to the amount of water in the spaces containing one, two, three or four water layers, respectively. We present the external water (Fig. 7a,b) which is the difference between the measured total water content and the water in interlayer spaces, i.e. the $V 1, V 2, V 3$ and $V 4$ filling interlayer pores.

For low suction pressures (several $\mathrm{kPa}$ ), the proportion of external water appears very high compared to the different volumes $V 1, \ldots, V 4$. 


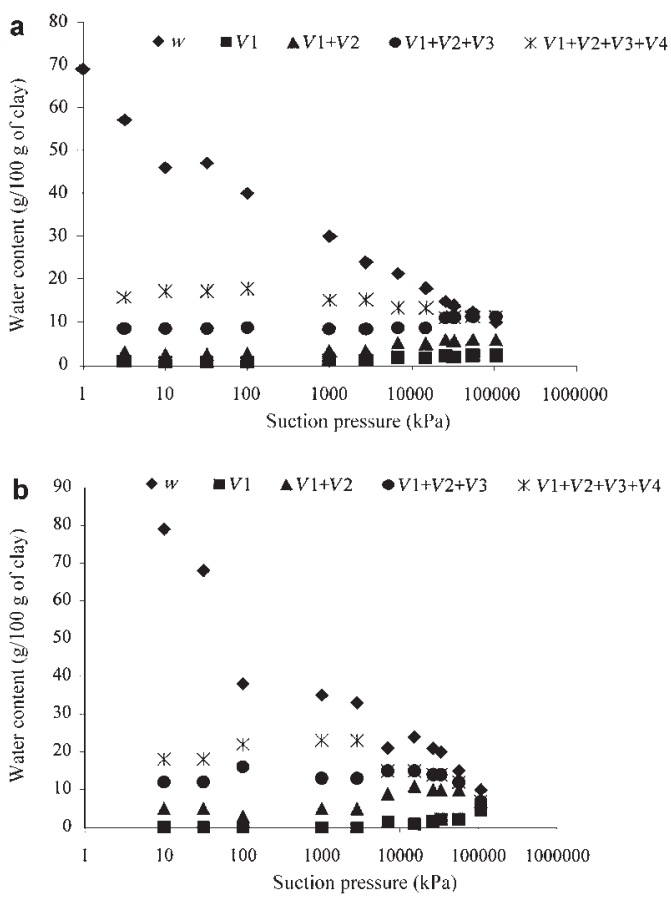

FIG. 7. Water distribution in FoCa7 (a), and MX80 (b) as a function of suction pressure. $\mathrm{w}$ is the total water content in the sample. $V 1$ to $V 4$ are the water amounts in the interlayer spaces containing 1 to 4 water layers.

However, when water content decreases, external water decreases, and the proportion of water in the volumes $V 1, \ldots, V 4$ increased. This means that, when the clay approaches a dry state, water is only present between the clay layers and there is nearly no external pore water. By contrast, if we move towards wet states, the quantity of external water becomes large and its proportion compared to the interlayer water is considerably higher.

After establishing the existence of different kinds of water corresponding to different pore sizes, it is clear that swelling occurs in two steps: first, an insertion of adsorbed water between clay layers, which is accompanied by a division of initial particles. Afterwards, the particles are separated by distances which are $>21.6 \AA$. Water between the clay layers induces less swelling than the interquasi-crystals water. It is likely that organized adsorbed water is mainly hydration around cations, whereas the swelling between particles (quasicrystals) with distances of $\sim 100 \AA$ is compatible with the existence of a diffuse double layer around the particle surface.
Swelling then involves different levels of organization. However, mechanically compacted clays cannot express their swelling properties correctly. It is thus not possible to use the traditional formalism of swelling (diffuse double layer) in reference to the total surface to model the properties. Swelling is essentially a subdivision of quasi-crystals and not an homogenous increase of interlayer distances. Quasi-crystal size, in relation to surface area, mainly determines the swelling properties.

\section{CONCLUSION}

Swelling experiments were carried out on two highly compacted $(60 \mathrm{MPa})$ clays. Hydration paths were conducted by subjecting the samples to different suction pressure values. The initial water content was $10 \%$ and after hydration at $1 \mathrm{kPa}$ reached $200 \%$ and $70 \%$ for MX80 and FoCa7, respectively.

The results confirm that the CEC of MX80 is greater than that of FoCa7 clay. As confirmed by data in the literature, the differences in clay swelling are mainly due to the nature of the saturating cation, i.e. $\mathrm{Na}$ or $\mathrm{Ca}$. The latter explains high water content values as measured for MX80. This change in behaviour seems to be a consequence of the very different texture between the clays as observed in other clays (Tessier \& Pédro, 1987): thin particles but large particles in ab plane for MX80 and thick but smaller ones in the $a b$ plane for FoCa7.

The measurements of the interlayer distances during hydration showed that the distances varied between 10 and $21.6 \AA$ and no more. This can be due to the effect of compaction which strongly limits swelling. In addition, the results confirmed that swelling involves two main stages. The hydration of a material at very low water content starts by a progressive insertion of water layers between the clay layers. Then, at the same time, an important division of the initial particles is observed. The consequence is an increase of the clay volume, which characterizes the swelling of the system.

While many results reported in the literature explain that clay swelling is mainly due to a change of the interlayer distances, the results of this work showed that changes in quasi-crystal size which induce changes in the specific surface are also a very important parameter for understanding 
compacted clay behaviour. The Pons model was used for estimating the interlayer distances; however, the clays were not well adapted for such a study because of the impurities due to the initial natural state.

\section{REFERENCES}

AFNOR (1994) Qualité des Sols. Recueil de normes françaises. AFNOR, Paris.

Aylmore L.A.G. \& Quirk J.P. (1962) The structural status of clay systems. Clays and Clay Minerals, $\mathbf{9}$, 104-130.

Ben Rhaïem H., Pons C.H. \& Tessier D. (1987) Factors affecting the microstructure of smectites. Role of cation and history of applied stresses. Pp. 292-297 in: Proceedings of the International Clay Conference, Denver, 1985 (L.G. Schultz, H. Van Olphen \& F.A. Mumpton, editors). The Clay Minerals Society, Bloomington IN.

Bruno G. (1993) Etude expérimentale des mécanismes de réduction et d'oxydation du Fer d'une argile naturelle - Evolution de ses propriétés physiques et chimiques. $\mathrm{PhD}$ thesis, Univ. Poitiers, France.

Ciesielsky H., Sterckeman T., Santerne M. \& Willery J.P. (1997) Determination of cation exchange capacity and exchangeable cations in soils by means of Cobalt Hexamine Trichloryde. Effects of experimental conditions. Agronomy, 17, 1-9.

Coulon H. (1987) Propriétés physico-chimiques des sédiments argileux français: Application au stockage des déchets radioactifs. $\mathrm{PhD}$ thesis, Univ. Lille, France.

Delville A. \& Laszlo P. (1990) The origin of the swelling of clays by water. Langmuir, 7, 1289-1294.

Elsass F., Beaumont A., Pernes M., Jaunet A.M. \& Tessier D. (1998) Changes in layer organisation of $\mathrm{Na}-$ and Ca-exchanged smectite during solvent exchanges for embedment in resin. The Canadian Mineralogist, 36, 1475-1483.

Gin S., Jollivet P., Mestre J.P., Jullien M. \& Pozo C. (2001) French SON 68 nuclear glass on alteration mechanisms contact with clay media. Applied Geochemistry, 16, 861-881.

Heilman M.D., Carter D.L. \& Gonzalez C.L. (1965) The Ethylene Glycol Monoethyl Ether EGME technique for determining soil-surface area. Soil Science, 100, 409-413.

Iñigo A.C., Tessier D. \& Pernes M. (2000) Use of X-ray transmission diffractometry for the study of clayparticle orientation at different water contents. Clays and Clay Minerals, 48, 682-692.

Kassif G. \& Ben Shalom A. (1971) Experimental relationship between swell pressure and suction. Geotechnique, 21, 245-255.
Kim J.M., Peacor D.R., Tessier D. \& Elsass F. (1995) A technique for maintaining texture and permanent expansion of smectite interlayer spacings for TEM observations. Clays and Clay Minerals, 43, 51-57.

Kjellander R., Marcelja S. \& Quirk J.P. (1988a) Attractive double-layer interactions between calcium clay particles. Journal of Colloid and Interface Science, 126, 194-211.

Kjellander R., Marcelja S., Pashley R.M. \& Quirk J.P. (1988b) Double-layer ion correlation forces restrict Calcium-clay swelling. Journal of Physical Chemistry, 92, 6489-6492.

Marcoen J.M. \& Tessier D. (1991) Critères de sélection des argiles comme barrières anti-pollution. Pp. 11-19 in: Aspects économiques de la gestion et du traitement des déchets ménagers et industriels. Environnement et Société, Fondation Universitaire Luxembourgeoise.

Méring J. (1946) Sur le processus de l'hydratation de la montmorillonite. Transactions of the Faraday Society, 42B, 205-219.

Norrish K. (1954) The swelling of montmorillonite. Faraday Society Discussion, 18, 120-134.

Pons C.H. (1980) Mise en évidence des relations entre la texture et la structure dans les systèmes eau-smectite par diffusion aux petits angles du rayonnement $X$ synchrotron. $\mathrm{PhD}$ thesis, Univ. Orléans, France.

Pons C.H., Rousseaux F. \& Tchoubar D. (1981) Utilisation du rayonnement synchrotron en diffusion aux petits angles pour l'étude du gonflement des smectites. I: Etude du système eau-montmorillonite$\mathrm{Na}$ en fonction de la température. Clay Minerals, 16, $23-42$.

Pons C.H., Tessier D., Ben Rhaïem H. \& Tchoubar D. (1982) A comparison between X-ray studies and electron microscopy observations of smectite fabric. Pp. 177-183 in: Proceedings of the International Clay Conference ( $\mathrm{H}$. Van Olphen \& F. Veniale, editors). Developments in Sedimentology, 35. Elsevier, Amsterdam.

Saiyouri N. (1996) Approche microstructurale et modélisation des transferts d'eau et du gonflement dans les argiles non saturées. $\mathrm{PhD}$ Thesis, Ecole Centrale de Paris, France.

Saiyouri N., Hicher P.Y. \& Tessier D. (2000) Microstructural approach and transfer water modelling in highly compacted unsaturated swelling clays. Mechanics of Cohesive-Frictional Materials, 5, $41-60$.

Suquet H. (1978) Propriétés de gonflement et de structure de la saponite. Comparaison avec la vermiculite. $\mathrm{PhD}$ thesis, Univ. Paris VI, France.

Tessier D. (1975) Recherches expérimentales sur l'organisation des particules dans les Argiles. Engineering thesis, Conservatoire National des Arts et Métiers, Paris.

Tessier D. (1978) Etude de l'organisation des argiles 
calciques. Evolution au cours de la desiccation. Annales d'Agronomie, 29, 319-355.

Tessier D. (1984) Etude expérimentale de l'organisation des matériaux argileux. $\mathrm{PhD}$ thesis, Univ. Paris 7, Institut National de la Recherche Agronomique, Paris, France.

Tessier D. (1991) Behaviour and microstructure of clays minerals. Pp. 387-415 in: Soil Colloids and their Associations in Aggregates (M. de Boodt, M. Hayes $\&$ A. Herbillon, editors). Plenum Press, New York.

Tessier D. \& Berrier J. (1979) Utilisation de la microscopie électronique à balayage dans l'étude des sols. Observation des sols humides soumis à différents pF. Sciences du Sol, 1, 67-82.

Tessier D. \& Pédro G. (1987) Mineralogical characterization of 2:1 clays in soils: Importance of the clay texture. Pp. 78-84 in: Proceedings of the International Clay Conference, Denver 1985 (L.G. Schultz, H. Van Olphen \& F.A. Mumpton, editors). The Clay Minerals Society, Bloomington IN.
Tessier D., Lajudie A. \& Petit J.C. (1992) Relation between the macroscopic behavior of clays and their microstructural properties. Applied Geochemistry, Supplementary Issue, 1, 151-161.

Tessier D., Dardaine M., Beaumont A. \& Jaunet A.M. (1998) Swelling pressure and microstructure of an activated swelling clay with temperature. Clay Minerals, 33, 255-267.

Warkentin B.P., Bolt G.H. \& Miller R.D. (1957) Swelling pressure of montmorillonite. Soil Science Society Proceedings, 21, 495-497.

Yong R.N. (1999) Soil suction and soil-water potentials in swelling clays in engineered clay barriers. Engineering Geology, 54, 3-13.

Yong R.N., Taylor L.O. \& Warkentin B.P. (1963) Swelling pressure of sodium montmorillonite at depressed temperatures. Proceedings of the $11^{\text {th }}$ National Conference, Clays and Clay Minerals, 2, 268-281. 